\title{
The outcomes of neglecting native language teaching
}

Natia Botkoveli

Vytautas Magnus University, Lithuania

https://doi.org/10.36505/ExLing-2020/11/0016/000431

\section{Background information}

The republic of Georgia is one of the most linguistically diverse regions in the Caucasus. As other multilingual countries Georgia is also facing difficult decisions concerning which national or official languages to use in administrative and education sectors. On the surface, the ethnic situation in Georgia seems to be well managed; however it cannot be said about the language situation. One of the issues that leads to confusion and is possibly the most discussed issue by Georgian linguists is the undefined status of the WestKartvelian languages, i.e. Megrelian and Svan. Svans, with a population of about 5,500, are mostly located in the high valleys along the Enguri and Tskhenistskali rivers in Western Georgia. Megrelians, around half a million, live in the capital and in the western Georgian lowlands (Jorbenadze 1991:15).

Investigating the status of Megrelian and Svan is a sensitive matter. The most discussed question in contemporary Georgian sociolinguistics is the qualification of these linguistic codes as languages or dialects. Some scientists (Gvantseladze 2006; Putkaradze 2010) consider them to be dialects of Georgian. Their opinion is mainly based on two arguments (Putkaradze 2010: 138, 139), however Wheatly (2009) argues that using purely objective criteria it is hard to argue that Megrelian and Svan are dialects of Georgian since they are not mutually comprehensible with Georgian (Wheatly 2009: 28).

Megrelian and Svan never gained the status of the permanent literary language during the Soviet period, a number of books, journals and newspapers were produced (mostly in Megrelian) (Jorbenadze1991: 22), which has not happened in cases of other dialects of Georgian (Dragojevic et al. 2014: 20). According to the leading opinion in Kartvelology, both Megrelian and Svan are languages, related to Georgian and these three languages comprise the same language family.

\section{Methodology}

The practical aim of this paper is to identify the existing challenges of the current education and language management and demonstrate the factors that are caused by the omission Megrelian and Svan in the education policy. This study is a first attempt in the Georgian linguistic tradition to address the current

ExLing 2020: Proceedings of 11 th International Conference of Experimental Linguistics, 12-14 October 2020, Athens, Greece 
language policy and language management from the different points of views in order to investigate:

(1) How does the current language management affect the unrecognized West-Kartvelian languages?

(2) What are the main obstacles for Georgian policymakers to achieve a multilingual policy?

The main objective of the study is to identify the difficulties of the current language management problems and support the development of Georgian language management, which will represent and sustain the diversity of the languages spoken in the country.

A qualitative semi-structured interview method was employed to elucidate the research questions and collect the data from the respondents involved in the current language management process. The obtained data represents the ideology of academia, government and language activists. I believe that understanding and analyzing different and often times contrasting views will contribute to a better understanding of the issues and finding solutions.

The study was conducted in Tbilisi, the capital of Georgia, which gathers professionals from around the country, including Samegrelo and Svaneti. All interviews were carried out in an indoor location, typically in a house or in the office. In each case, there was one interviewer and one respondent only. The interviews were carried out as informal conversations to ensure a relaxed atmosphere so that the interviewees felt comfortable to talk freely. In order to ensure the maximum of their openness and privacy, they were informed in advance that none of their personal information was going to be heard in the audio or shown in the transcript.

The criteria for choosing the interviewees was based on the initial aims of the study to approaches the topic from three different viewpoints:

(i) Authorities, which made it possible to identify the existing problems of language management - 4 interviews totalling 128.72 minutes;

(ii) Researchers of Svan/Megrelian languages, who discussed the challenges academia members face due to lack of interest towards the WestKartvelian languages - 4 interviews totalling 136.48 minutes.

(iii) Language activists, who experience the shortcomings of the current policy- 3 interviews totalling 184.29 minutes.

After transcribing the interviews verbatim, data were analyzed using content analysis. While the content analysis can be carried out at different levels of depth, my interest was an in-depth and comprehensive understanding of the problems caused by the omission of Megrelian and Svan in the language management processes.

\section{Results and discussion}

The study demonstrated that current education policy supposedly leads to the endangerment of the West-Kartvelian languages. Respondents claim, that the 
modern linguistic management can be a reason for problem, which was confirmed on the international level as well.

According to the document titled "Language Vitality and Endangerment" (www.unesco.org) compiled by UNESCO in 2003, Megrelian and Svan languages are described as Definitely Endangered. According to Atlas of the World's Languages in Danger, children no longer learn the languages as mother tongue in the home.

Noticing the problem of endangerment was a turning point for the all language activists I interviewed within this research. Respondent \#6, shared his observations that even his parents are unable to speak the "same" Megrelian as his grandmother used to speak.

Respondent \#3, who has rich experience of fieldwork in Samegrelo, is convinced that for all children born in Samegrelo in the recent years, the L1 is Georgian. She shared that some Megrelian parents are even proudly claiming that their children barely speak Megrelian and the new generations are already fluently expressing themselves in Georgian. Very similar information was provided by the respondent \#5, who shared her experience with Svan children in the high mountainous villages of Svaneti:

"At the very beginning I was thinking that it was only the children from the bigger settlement who did not speak proper Svan, but after observing the villagers, I noticed that they too were using Georgian only... I was shocked!"

I asked my respondents to identify the reasons for this tendency. Respondent \#3 believes that there are two main factors that cause this problem: (i) the lack of prestige of the West-Kartvelian languages; (ii) the negative attitudes towards the accent and intonation Megrelian and Svan speakers have while speaking in Georgian.

During this research the grass-root officials were asked to discuss the reasons hindering the introduction of Megrelian and Svan at the school level. It turned out that Georgia lacks a language policy document. Respondent \#9 explained that the State Language Department is working on the new language policy document, which will include a ten year strategy for language management.

Meanwhile, young Megrelian and Svan speakers are discouraged from studying and researching the West-Karvelian languages. Researcher \#5 suggests that the factors, which lead to a lack of motivation to learn or deepen their knowledge in Megrelian and Svan are easy to explain as there are no career opportunities in these languages:

"Imagine someone born in the capital, why would they "waste" their time on learning Megrelian and Svan when they can learn something more useful like English or German?” 
I was given a chance to hear from the those who do not admit that the problem of endangerment is real. Respondent \#9, who occupies one of the head positions in the State Language Department, argues that the criteria for determining the endangered languages lack accuracy. She claims that several years ago Megrelian and Svan were not included in the UNESCO's list of endangered languages. According to her there was no clear evidence that the number of the West-Kartvelian language speakers decreased drastically in the last two decades. She suggests that some criteria for assessing the level of endangerment are somehow misleading:

"If we compare Megrelian and Svan we will notice that they have quite different qualitative and quantitative indices of their native speakers. Megrelian is being spoken by more than a million speakers, whereas Svan is being used by less than

3000 people. It is obvious which one is endangered, but both are in the list."

The discussion regarding the endangerment of the West-Kartvelian Languages highlights the large diversity in attitudes and beliefs. The key takeaway is that the respondents had strong feelings related to the endangerment of Megrelian and Svan languages. One of the main reasons for this topic being so touchy might be the fact that the majority (7) of my respondents have Megrelian and Svan backgrounds. The officials have expressed controversial ideas on this issue, which once again demonstrated the need for discussions where all parties could be involved.

In summary, for the majority of the participants limited education in Megrelian and Svan seems to be a serious problem as well as a possible reason for the language endangerment. Despite the language activists' strong desire to introduce the West-Kartvelian languages in schools some researchers and authorities do not approve of this idea. Supposedly, until adopting the new language and education policies the future of education accessible in Megrelian and Svan remains undecided.

\section{References}

Dragojevic, Marko and Berglund, Christofer and Blauvelt, Timothy. 2014. Attitudes Towards Tbilisi and Mingrelian-Accented Georgian Among Georgian Youth: On the Road to Linguistic Homogenization? Tbilisi: Iliauni Press.

Jorbenadze, Besarion. 1991. The Kartvelian Languages and Dialects. Tbilisi: Mecniereba.

Putkaradze, Tariel and Dadiani, Eka and Sherozia, Revaz. 2010. European Charter for Regional or Minority Languages and Georgia (Sakartvelo). Kutaisi: Kutaisi Publishing Center.

Wheatley, Jonathan. 2009. Georgia and the European Charter for Regional or Minority Languages Flensburg: European Centre for Minority Issues (ECMI).

Atlas of the World's Languages in Danger 2011.

http://www.unesco.org/new/fileadmin/MULTIMEDIA/HQ/CLT/pdf/abo utEndangeredLanguages-WV-EN-1.pdf (date of retrieval: 20 August 2020). 